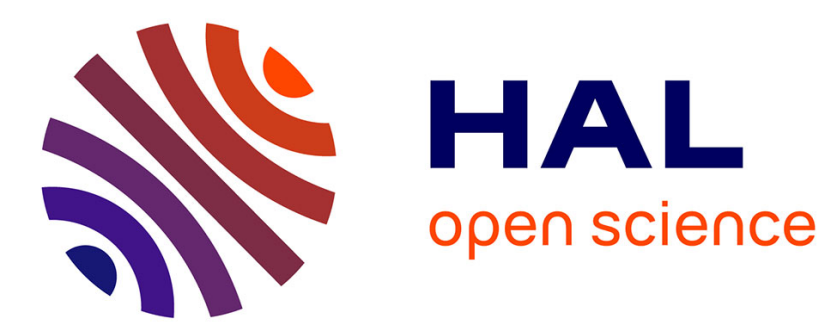

\title{
Forest Invasion by the African tulip tree (Spathodea campanulata) in the Hawaiian Islands: Are Seedlings Shade-Tolerant?
}

Sébastien Larrue, Curtis C. Daehler, Franck Vautier, Jennifer L. Bufford

\section{- To cite this version:}

Sébastien Larrue, Curtis C. Daehler, Franck Vautier, Jennifer L. Bufford. Forest Invasion by the African tulip tree (Spathodea campanulata) in the Hawaiian Islands: Are Seedlings Shade-Tolerant?. Pacific Science, 2014, 68 (3), pp.345-358. hal-01122865

\section{HAL Id: hal-01122865 https://hal.science/hal-01122865}

Submitted on 13 Mar 2015

HAL is a multi-disciplinary open access archive for the deposit and dissemination of scientific research documents, whether they are published or not. The documents may come from teaching and research institutions in France or abroad, or from public or private research centers.
L'archive ouverte pluridisciplinaire HAL, est destinée au dépôt et à la diffusion de documents scientifiques de niveau recherche, publiés ou non, émanant des établissements d'enseignement et de recherche français ou étrangers, des laboratoires publics ou privés. 
Forest Invasion by the African tulip tree (Spathodea campanulata) in the Hawaiian Islands: Are Seedlings Shade-Tolerant?

Sébastien Larrue ${ }^{(1) 1}$, Curtis Daehler ${ }^{(2)}$, Franck Vautier ${ }^{(3)}$ and Jennifer L Bufford ${ }^{(2)}$

(1) GEOLAB UMR/CNRS 6042, Université Blaise Pascal, 4 rue Ledru, 63057 Clermont-

Ferrand cedex, France

${ }^{(2)}$ Department of Botany, University of Hawai ‘i at Manoa, Honolulu, 3190 Maile Way, Room 101, HI 96822, USA

${ }^{(3)}$ Université Blaise Pascal, 4 rue Ledru, 63057 Clermont-Ferrand, France

\footnotetext{
${ }^{1}$ Corresponding author: email; sebastien.larrue@univ-bpclermont.fr
} 
2 Abstract: Native to West Africa, Spathodea campanulata (African tulip tree) is frequently

3 viewed as a shade-intolerant invader. It commonly colonizes roadsides, human-disturbed

4 forests and abandoned agricultural land in tropical islands, where it can then become

5 dominant in secondary forests. Some authors have suggested that the seedlings may be shade-

6 tolerant and able to establish in closed forest, but the shade tolerance of seedlings has never

7 been evaluated. We identified tolerated light environments of $S$. campanulata seedlings in wet

8 forests in Hawaii by measuring photosynthetically active radiation (PAR) around naturally

9 occurring seedlings $(<30 \mathrm{~cm}$ height $)$ in the field. We also measured photosynthetic responses

10 of seedlings to light under field and lab conditions, and determined seedling growth rates in

11 sun and shade. Seedlings were found in shaded conditions in the field, and they consistently

12 had positive net carbon gain at $50 \mu \mathrm{mol}$ photons $\mathrm{m}^{-2} \cdot \mathrm{s}^{-1} \mathrm{PAR}$, with an estimated mean

13 compensation point below $10 \mu \mathrm{mol}$ photons $\mathrm{m}^{-2} \cdot \mathrm{s}^{-1}$, indicating high shade tolerance. The most

14 frequent midday light environments of S. campanulata seedlings in the field were in the range

15 around 50 to $200 \mu \mathrm{mol}$ photons $\mathrm{m}^{-2} \cdot \mathrm{s}^{-1} \mathrm{PAR}$, i.e., $2.5 \%$ to $10 \%$ of full sunlight. Among

16 seedlings found growing in shade, minimum saturating light $\left(\mathrm{E}_{\mathrm{k}}\right)$, determined from

17 chlorophyll fluorescence, averaged $260 \mu \mathrm{mol}$ photons $\mathrm{m}^{-2} \cdot \mathrm{s}^{-1}$, suggesting that seedling

18 maximum photosynthesis can occur at less than $13 \%$ of full sun. Growth rates of young

19 seedlings in shade and sun were comparable. Widespread wind dispersal of seeds, seedling

20 tolerance of low light, and our observations of some $S$. campanulata saplings establishing in

21 rainforest without recent disturbance suggest that $S$. campanulata will be a persistent

22 component of Hawaiian lowland rainforests. 


\section{Introduction}

3 Many studies show that invasive species can pose important threats to native biodiversity (Hierro et al. 2005, Mack et al. 2000) or cause major problems in natural ecosystems (Merlin and Juvik 1992), especially on tropical islands (Daehler 2005, Denslow 2003, Loh and Daehler 2007, Kueffer et al. 2010, Meyer and Florence 1996, Meyer 2004, Reaser et al. 2007). The invasiveness of introduced plants in new geographic areas has been explained by characters such as competitive advantages under particular environmental conditions (Daehler 2003, Mooney et al. 2005), or possession of novel chemical traits compared with the native flora in the introduction area (Callaway and Ridenour 2004). Certain invasive plants, such as Spathodea campanulata, have attracted particular interest because of their successful spread across numerous tropical islands (Labrada and DiazMedina 2009). Spathodea campanulata P. Beauv. (Bignoniaceae), commonly called African tulip tree, is widely naturalized in many Pacific islands and considered a threat to native biodiversity (Meyer 2000, Pacific Islands Ecosystems at Risk 2011), notably by creating a shading effect, which reduces native species richness under its canopy (Weber 2003). It is also reported as a serious agricultural weed, especially in coffee plantations (Labrada and DiazMedina 2009). Forests dominated by $S$. campanulata are frequently established in the lowland tropics on abandoned agricultural lands, deforested lands (Francis 2000, Labrada and DiazMedina 2009, Larrue 2011, Kress and Horvitz 2005) or in secondary rain forests (Bito 2007). Spathodea campanulata has been highlighted by the Invasive Species Specialist Group as among '100 of the World's Worst Invasive Alien Species' (ISSG 2004). Most invasive plants affect secondary forests, particularly in environments already highly disturbed by humans (Martin et al. 2008), but some invasive plants are able to grow in later-successional forests that have experienced little or no recent disturbance (Martin et al. 
1 2004, Meyer and Florence 1996, Rejmánek 1996). These shade-tolerant plants, many of

2 which are trees, pose a serious threat to the persistence of native forests (Martin et al. 2008,

3 2004, Meyer and Florence 1996). Therefore, it is especially important to identify potentially

4 shade-tolerant plant invaders so that they can be targeted as priorities for prevention or

5 control.

Spathodea campanulata is often described as a shade-intolerant invader (Francis and

7 Lowe 2000, Martin et al. 2008, Thompson et al. 2007) but there is some controversy in the

8 literature. Lambrada and DiazMedina (2009) report that the wind-dispersed seeds of $S$.

9 campanulata are able to breach the 'barrier effect' of large trees present in edges of the forest,

10 and these authors observed S. campanulata seedlings in native forests in Cuba, including

11 primary forests. Other authors have suggested that $S$. campanulata seedlings are shade-

12 tolerant and able to thrive without disturbance in rain forests (Anderson et al. 1992, Smith

1985, Staples and Cowie 2001). Little quantitative information is available on shade tolerance

14 of S. campanulata seedlings, although such information is important for understanding invasion patterns and potential. Francis (1990) reported that $S$. campanulata seedlings grew well in $~ 50 \%$ shade, developing true leaves within 2 months. Labrada and DiazMedina (2009)

17 indicated that the shade or semi shade of coffee plantations is the most favourable light environment for S. campanulata seed germination in Cuba and noted that higher seed germination occurs in semi-shade ( $50 \%$ shade) than in full sunlight, but no attempt was made to assess growth at lower light levels. In this study, we examined field distribution

21 patterns and photosynthetic and growth capacities of $S$. campanulata seedlings on Oahu and 22 Hawaii (Hawaiian Islands) in order to characterize and quantify the light environments under which S. campanulata seedlings are currently establishing and capable of growing. 


\section{Field study sites}

The volcanic islands of Oahu and Hawaii (Hawaiian Islands) are found in the Pacific Ocean between $18^{\circ} 54^{\prime} 41^{\prime \prime}-21^{\circ} 42^{\prime} 34^{\prime \prime} \mathrm{N}$, and $154^{\circ} 48^{\prime} 29^{\prime \prime}-158^{\circ} 16^{\prime} 46^{\prime \prime} \mathrm{W}$. The island of Oahu ranges from sea level to $1,220 \mathrm{~m}$ asl with a land surface of $1,545.3 \mathrm{~km}^{2}$; the island of Hawaii occupies an area of $10,432 \mathrm{~km}^{2}$ with a highest summit at 4,205 m asl (State of Hawaii Data Book 2004). Both islands have a leeward dry side and a windward wetter side exposed to the dominant north-eastern trade winds. The mean annual rainfall in the surveyed area of Oahu ranges from 2,001 to $2,750 \mathrm{~mm}$, and from 3,551 to $4,400 \mathrm{~mm}$ for the Hawaii site (Giambelluca et al. 2011).

The most important invasion of S. campanulata is observed between sea level and 226 $\mathrm{m}$ asl on the windward coast of Oahu and up to $312 \mathrm{~m}$ asl in Hawaii, in the "moderately drymoist seasonal zone" and "lowlands rainforest zone" (Mueller-Dombois 2002). Study sites were located on the windward side, at the foot of the Ko'olau mountains (island of Oahu) and on the gentle downslope of Mauna Kea (island of Hawaii) in the lowland rainforest zone

(Fig.1). In these wet forests, some native species remain (e.g., Psychotria mariniana

(Rubiaceae), Freycinetia arborea (Pandanaceae), Metrosideros polymorpha (Myrtaceae), and Syzygium sandwicensis (Myrtaceae)), but the forests are now dominated by $S$. campanulata and other introduced trees species, e.g., Cecropia peltata (Urticaceae), Aleurites moluccana (Euphobiaceae), Cinnamomum burmannii (Lauraceae), Falcataria moluccana (Fabaceae), Psidium cattleianum (Myrtaceae), and Schefflera actinophylla (Araliaceae). $<$ Figure 1. near here $>$

\section{Study species}

Spathodea campanulata is a large evergreen tree, 20-25 m in height (Keay 1957, Neal 1948, Smith 1985) but sometimes reaching more than $30 \mathrm{~m}$ (Unwin 1920), with a dense 
1 irregular crown and a trunk diameter of 0.5-1.75 m (Holdridge 1942, Little and Skolmen

2 1989). This species grows rapidly (Francis 1990, Pacific Islands Ecosystems at Risk 2011;

3 around $2 \mathrm{~m}$ per year in young stands (S. Larrue, personal observation)) and produces

4 numerous red-orange flowers pollinated by bats and birds in its native range (Keay 1957).

5 The species requires cross-pollination (Bittencourt et al. 2003); the fruit is a brown pod

6 containing about 500 wind-dispersed seeds (Fosberg et al. 1993, Little and Skolmen 1989).

7 Mature individuals of S. campanulata produce many pods, with 125,000 (Holdridge 1942) to

8290,000 (Francis and Rodríguez 1993) seeds $\mathrm{kg}^{-1}$ of pods. The species is mainly propagated

9 by seeds, which can travel long distances (Francis 1990, Little and Skolmen 1989, Staples et

10 al. 2000).

11 The native geographic area of $S$. campanulata extends from the west coast of Africa to central

12 Africa between $12^{\circ} \mathrm{N}$ and $12^{\circ} \mathrm{S}$ (Irvine 1961). The tropical climate of the native range of

13 African tulip tree is warm and wet, with a monthly mean temperature of $27^{\circ} \mathrm{C}$ to $30^{\circ} \mathrm{C}$ and

14 abundant rainfall (Francis 1990). Spathodea campanulata has a broad ecological range

15 (Florence 1997, Francis 1990) and therefore has been successfully grown throughout the

16 tropics (Bärtels 1993, Francis 1990). It can survive in areas with a dry season of 1-3 mo;

17 successful reproduction is reported at a minimum of $1,300 \mathrm{~mm}$ of mean annual precipitation.

18 Substrate can be basic or acid soils, from clayey soil to loamy sands, with poor to excessive

19 soil drainage (Francis 1990). The species is frost sensitive (Eliovson 1969) and apparently

20 needs nearly full sunlight for reproduction (Little and Skolmen 1989).

21 In c. 1915, S. campanulata was introduced as an ornamental tree on Oahu (Staples and Herbst 22 2005). It is currently naturalized in lowland coastal plains on the windward side of the islands 23 of Kauai, Oahu, Molokai, Maui and Hawaii (Wagner et al. 1999). In the Hawaiian Islands, $S$. 24 campanulata ranges from sea level up to $1,000 \mathrm{~m}$ asl (Smith 1985). It is also found from sea 25 level to 1,200 $\mathrm{m}$ asl in Puerto Rico (Francis 1990) and up to 1,430 $\mathrm{m}$ asl in the main island of 
1 Tahiti (Society Islands, French Polynesia) (Meyer, pers. comm.). In Hawaii, Smith (1985)

2 reported major infestations in almost every rainforest in East Maui and along the valley of

3 northern and eastern slopes of Kauai and Oahu. Loope et al. wrote (1992, p. 567): "It [S.

4 campanulata] should be monitored and opportunistically controlled in conjunction with

5 systematic control of strawberry guava and other rainforest weeds."

6

7

\section{Plot-based seedling counts and photosynthetically active radiation}

Field studies were conducted from January-February, 2012. In forests with canopy dominated by $S$. campanulata, three $150 \mathrm{~m}^{2}$ field plots were delineated. In the plots, we counted (1) the number of seedlings $\left(<30 \mathrm{~cm}\right.$ height) positioned in $1-\mathrm{m}^{2}$ quadrats $(\mathrm{n}=150$ per plot), and (2) recorded the photosynthetically active radiation (PAR) in each $1 \mathrm{~m}^{2}$ quadrat (systematic random sample). The PAR was recorded with a $0.3-\mathrm{m}$ line sensor (Fieldscout PARmeter, Spectrum Technologies) at the centre of every $1 \mathrm{~m}^{2}$ quadrat at $40 \mathrm{~cm}$ above the ground $( \pm 10 \mathrm{~cm})$. The PAR measurements in the three plots were made between $12 \mathrm{~h} 00$ and 13 h00 (i.e. near solar noon) during cloudless days. PAR was also measured in full sunlight at around $12 \mathrm{~h} 30\left( \pm 3.5 \mu \mathrm{mol}\right.$ photons $\left.\mathrm{m}^{-2} \cdot \mathrm{s}^{-1}\right)$.

\section{Interpolation of PAR}

In order to map the light environment and estimate the mean light environment in the three plots between $12 \mathrm{~h} 00$ and $13 \mathrm{~h} 00$, field light readings were entered into a Geographic Information System (see Figure 2; Geographic Information System Mapinfo Professional v.10, Interpolation Method). We then superimposed positions of the S. campanulata seedlings onto these plot maps and extracted the projected mid-day PAR value for each seedling. $<$ Figure 2. near here $>$ 


\section{Photosynthetically active radiation recorded along the line transect}

In order to quantify seedling establishment across a wider range of light environments (including mid-day full sun), S. campanulata seedlings were surveyed along an abandoned section of roadside (1,590 m of length, Old Auloa Road, Oahu; both ends of road transect: $21^{\circ} 22^{\prime} 17.96^{\prime \prime} \mathrm{N}-157^{\circ} 47^{\prime} 05.34^{\prime \prime} \mathrm{W}$, and $\left.21^{\circ} 22^{\prime} 22.65^{\prime \prime} \mathrm{N}-157^{\circ} 47^{\prime} 29.55^{\prime \prime} \mathrm{W}\right)$. We recorded the PAR (between $12 \mathrm{~h} 00$ and 13h00) above each $S$. campanulata seedling ( $<30 \mathrm{~cm}$ height) encountered between 0 and $2 \mathrm{~m}$ from the roadside and compared the distribution of light readings at the seedlings to the distribution of available light environments along the roadside (random points $\sim 30 \mathrm{~cm}$ above the ground).

\section{Correlation between spatial pattern of seedlings and PAR values}

In order to test any correlation between photosynthetically active radiation and the spatial pattern and abundance of $S$. campanulata seedlings, we conducted the following analysis: We compared the distribution of PAR readings among the three plots and along the line transect to the distribution PAR readings at $S$. campanulata seedlings using a

Kolmogorov-Smirnov test (XLStat ${ }^{\circledR}$ software, version 2007.6). We then tested whether some light environments are more frequently colonized by seedlings than expected. We compared these results to the photosynthetic responses of $S$. campanulata seedlings in controlled light environments.

\section{Photosynthetic and growth responses of seedlings}

Ten seedlings were excavated from shaded or partially shaded environments located near the beginning of the survey transect. Seedlings were transported to the laboratory for photosynthetic measurements after allowing 2-5 days for recovery from any potential shock of transplantation. A chlorophyll fluorometer (PAM 2500, Heinz Walz GmbH) was used to 
1 measure the minimum saturating light level $\left(\mathrm{E}_{\mathrm{k}}\right)$ for ten seedlings. Additionally,

2 photosynthetic measurements were made between $10 \mathrm{~h} 00$ and $14 \mathrm{~h} 00$ with a photosynthesis meter (CI 340, CID Bio-Science, Inc.) and light response curves were used to estimate the light compensation point (minimum light required for plant maintenance). In order to confirm results from lab-transported field seedlings, additional light response curves were recorded directly in the field for seven seedlings found growing naturally in shaded environments.

To measure seedling growth rates in response to shade, lab-germinated seeds were transplanted into $16 \mathrm{~cm}$ conetainers containing a 3:1 mixture of Premier Promix Bx Mycorrhizae (Premier Tech Horticulture) and small black cinders $(<2.5 \mathrm{~cm}$, Niu) with fertilizer (Osmocote 14-14-14 NPK, $0.055 \mathrm{~g}$ ). Seedlings were placed on an outdoor bench in sun $\left(\mathrm{n}=5\right.$, mean daily PAR $1300 \mu \mathrm{mol}$ photons $\mathrm{m}^{-2} \cdot \mathrm{s}^{-1}$, range 143 to 2156$)$ or shade $(\mathrm{n}=6$, mean daily PAR $138 \mu \mathrm{mol}$ photons $\mathrm{m}^{-2} \cdot \mathrm{s}^{-1}$, range 6 to 276) and grown under well-watered conditions until reaching the four-leaf stage (28-78 days, mean 56 days), at which time seedlings were harvested to determine relative growth rates, based on total dry mass. although a few other introduced woody species were also recorded (Table 1). A total of $97 \mathrm{~S}$. campanulata seedlings were found. Seedlings height ranged from 3 to $18 \mathrm{~cm}$ with a mean height of $10 \mathrm{~cm}$. Among plots, S. campanulata seedling density ranged from 0.04 to $0.54-\mathrm{m}^{2}$ (Table 1). The local-scale light environment within the three plots, as characterized by midday PAR measurements, ranged from $1 \%$ full sunlight (observed in all three plots) to 58.7\% full sunlight (plot 3). Among the three surveyed plots, the median light environment ranged from $1 \%$ to $4.1 \%$ full sunlight (Table 1 ). 
1

\section{Spatial pattern of seedlings and distribution of PAR values in the plots}

The overall distribution of seedlings among light environments differed significantly

from the distribution of available light environments in the plots (Kolmogorov-Smirnov test, maximum distance $=0.541, \mathrm{P}<0.001)$. This difference in distributions was examined more closely by grouping PAR values into categories and plotting expected frequency of seedling occurrence (frequency of light environments in the plots) versus actual frequency of seedling occurrence among light environments in the plots (Figure 3). Within the lowest light ranges $\left(<20 \mu \mathrm{mol}\right.$ photons $\left.\mathrm{m}^{-2} \cdot \mathrm{s}^{-1}\right)$, seedlings are under-represented, whereas they are well represented or over-represented at the midday ranges of 51-200 $\mu \mathrm{mol}$ photons $\mathrm{m}^{-2} \cdot \mathrm{s}^{-1}$ (Figure 3) suggesting that this latter range may be a preferred light environment.

\section{Seedlings and distribution of PAR values along the line transect}

Along the line transect, 255 S. campanulata seedlings were recorded, ranging from 4 to $27 \mathrm{~cm}$ in height with a mean height of $12.5 \mathrm{~cm}$. The midday PAR values above seedlings ranged from $0.4 \%$ to $100 \%$ full sunlight $\left(1895 \mu \mathrm{mol}\right.$ photons $\left.\mathrm{m}^{-2} \cdot \mathrm{s}^{-1}\right)$, and the median PAR was $193 \mu \mathrm{mol}$ photons $\mathrm{m}^{-2} \cdot \mathrm{s}^{-1}$. The midday light environments along the line transect estimated by 102 random points, ranged from 10 to $1319 \mu$ mol photons $\mathrm{m}^{-2} \cdot \mathrm{s}^{-1}$.

Along the line transect, the highest $S$. campanulata seedling densities occurred within the ranges of $50-150 \mu \mathrm{mol}$ photons $\mathrm{m}^{-2} \cdot \mathrm{s}^{-1}$ midday PAR (Figure 4). The PAR readings from random points along the transect demonstrate the seedling dis-proportionately occupy low light environments (Figure 4). Among the observed 255 seedlings on the transect, only three seedlings were found in full sunlight (between 1888 and 1895 PAR).

$<$ Fig. 3 near here $>$ $<$ Fig. 4 near here $>$ 


\section{Photosynthetic and growth rate measurements}

Field-collected seedlings averaged $7.6 \mathrm{~cm}$ tall $($ range $=3-14.5 \mathrm{~cm})$ with an average of

5.7 leaves (range $=4-8$ ). Overall, net photosynthetic rates of the seedlings were relatively

5 low, with a maximum of around $3 \mu \mathrm{mol} \mathrm{CO} \mathrm{m}^{-2} \cdot \mathrm{s}^{-1}$ (Figure 5). Nevertheless, seedlings

6 consistently had positive photosynthetic rates down to $50 \mu \mathrm{mol}$ photons $\mathrm{m}^{-2} \cdot \mathrm{s}^{-1}$. The estimated 7 compensation point was $10 \mu \mathrm{mol}$ photons $\mathrm{m}^{-2} \cdot \mathrm{s}^{-1}$ (x-intercept of Figure 5). The results of 8 photosynthetic measurements on naturally established field seedlings growing in shade were

9 similar: the estimated compensation point was around $10 \mu \mathrm{mol}$ photons $\mathrm{m}^{-2} \cdot \mathrm{s}^{-1}$, the net

10 photosynthetic rates of the seedlings were around $2.5 \mu \mathrm{mol} \mathrm{CO} 2 \mathrm{~m}^{-2} \cdot \mathrm{s}^{-1}$ (Figure 6).

Minimum saturating light $\left(\mathrm{E}_{\mathrm{k}}\right)$ determined from chlorophyll fluorescence averaged

12 $260 \mu \mathrm{mol}$ photons $\mathrm{m}^{-2} \cdot \mathrm{s}^{-1}\left(\right.$ range $=178-375 \mu \mathrm{mol}$ photons $\left.\mathrm{m}^{-2} \cdot \mathrm{s}^{-1}\right)$ and this corresponds closely with the minimum saturating light as seen from lab-transported seedlings (180-400 $\mu \mathrm{mol}$ photons $\mathrm{m}^{-2} \cdot \mathrm{s}^{-1}$, Figure 5) and field-measured seedlings $\left(\sim 150 \mu \mathrm{mol}\right.$ photons $\mathrm{m}^{-2} \cdot \mathrm{s}^{-1}$, Figure 6). Average relative growth rate of sun-grown seedlings was not statistically greater than that of shade-grown ( $10 \%$ full sun) seedlings (Figure 7$)$.

$<$ Fig. 5 near here $>$

$<$ Fig. 6 near here $>$

Our results show that seedlings in the field were tolerant of mid-day PAR levels of $<50 \mu \mathrm{mol}$ photons $\mathrm{m}^{-2} \cdot \mathrm{s}^{-1}$ (Figures 2-3), but the most frequent environment for S. campanulata seedlings was between 50 and $200 \mu \mathrm{mol}$ photons $\mathrm{m}^{-2} \cdot \mathrm{s}^{-1}$ (Figure 3 and 4). These results show that seedlings commonly colonize light environments between $2.5-10 \%$ of full sun in the field.

Shade environments have been defined as 4\%-10\% of full sun (Denslow et al. 1990, Kitajima 
1 1994, Baruch et al. 2000 Schumacher et al. 2008). Therefore, we classify many of these $S$.

2 campanulata seedlings as growing in shaded environments. Nevertheless, it must be

3 acknowledged that mid-day point measurements of PAR provide only a rough snapshot of the

4 daily light environment in the understorey. Seedlings may experience extreme fluctuation in

5 light conditions from long periods of low light alternating with brief, unpredictable periods of

6 high light during sunflecks (see e.g., Canham et al. 1990, Chazdon 1988, Leakey et al. 2005,

7 Pearcy et al. 1994, Rijkers et al. 2000). Consequently, our mid-day PAR measurements may

8 underestimate light availability to some $S$. campanulata seedlings during other parts of the

9 day, while for other seedlings, our mid-day PAR estimates may represent maximum PAR

10 availability, with lower PAR available in other parts of the day. Because of the inability of

11 mid-day PAR measurements to capture potential variability in PAR throughout the day, it is

12 important to also compare seedling photosynthetic responses to varying light availability.

13 Shade-grown seedlings had net carbon gains from photosynthesis at very low light levels (50-

$14100 \mu \mathrm{mol}$ photons $\left.\mathrm{m}^{-2} \cdot \mathrm{s}^{-1} \mathrm{PAR}\right)$, and of particular interest was the fact that these shade-grown

15 seedlings had low light saturation levels (Figures 4 and 5), suggesting that they would not

16 benefit much from brief exposure to bright sunflecks.

17

18

19

Many tree species with little to no shade tolerance are known to support a "seedling bank" in a shaded understory, but these seedlings do not survive for long (Kobe et al. 1995). Based on our measurements of net productivity $\left(\mathrm{CO}_{2}\right.$ fixation) even at very low light levels, we expect long-term $S$. campanulata survival and slow growth under shaded forest conditions. In fact, in a separate field experiment, among freshly germinating seeds, seedling survival after one year under $<25 \%$ canopy openness averaged $38 \%$ (J. Bufford, unpublished data), which is high considering the many possible sources of early seedling mortality in the field. Furthermore, our observations in and around the field plots revealed evidence that a few 
1 saplings ( $<5 \mathrm{~m})$ were able to emerge from the understory shrub layer in shaded environments

2 (Table 1), though these represent only a small proportion of the potential establishment

3 indicated by much higher seedling abundance (Table 1; see Plot 3). Our findings lead us to

4 classify $S$. campanulata seedlings as shade-tolerant.

Considering that saturating photosynthesis in the $S$. campanulata seedlings occurred at

6 around $260 \mu \mathrm{mol}$ photons $\mathrm{m}^{-2} \cdot \mathrm{s}^{-1}$, it is remarkable that a few seedlings were also found in

7 completely open conditions on the line transect (Fig. 4). However, these full sun conditions

8 likely existed only for a short time around mid-day, as tall vegetation surrounding these

9 seedlings would have shaded them before and after mid-day. There is an overall inverse

10 correlation between the number of seedlings and mid-day PAR values along the line transect

11 (Spearman's, $\mathrm{r}_{\mathrm{s}}=-0.356, \mathrm{p}<0.0001$ ) implying that full sun is a non-preferred environment.

12 Lambrada and DiazMedina (2009) reported that the greatest abundance of young $S$.

campanulata was recorded in areas of abandoned coffee plantations, which indicates that the shade or semi-shade conditions of these plantations is a suitable habitat for S. campanulata growth. Overall, these results suggest that a minimum level of shade is beneficial for $S$. campanulata germination and early seedling growth, although it seems likely that larger plants can take advantage of higher light conditions. For example, in a separate field experiment, one plant in a sunny environment was observed to flower within one year after germination, while no $S$. campanulata seedlings in the shade reached maturity within a year (J. Bufford, unpublished data).

We have assumed that light environment is an important factor in early recruitment of S. campanulata seedlings, but other causal factors such as disease or seed dispersal patterns might be correlated with light environments and might therefore contribute to observed patterns of S. campanulata recruitment and invasion. Low soil water availability may also contribute to the low number of $S$. campanulata seedlings in high light environments. 
1 However, potted seedlings grown in full sunlight and watered regularly took as long or longer

2 to develop (compared to shaded plants) (Figure 7), and these sun-grown seedlings generally

3 had smaller, discolored leaves, with lower chlorophyll content (J. Bufford, unpublished data).

4 It seems likely that temperature stress and/or reduced humidity become an important

5 limitation under higher PAR conditions. We observed no signs of seedling predation at our

6 field sites, while herviory at other field sites on Oahu averaged $<10 \%$ of leaf area (J. Bufford,

7 personal observations).

Given that our plots were dominated by adult Spathodea, observed S. campanulata

9 seedling densities might be considered rather low, ranging from 0.04 to 0.54 seedlings $\mathrm{m}^{-2}$

10 (Table 1). In plots 1 and 2, light availability was very low (1 to $1.4 \%$ of full sun respectively;

11 see Table 1) and the ground was nearly bare, with no seedlings other than $S$. campanulata.

12 These plots show the limited recruitment of $S$. campanulata (i.e., seed germination and established seedlings) in such extremely shaded environments. In contrast, in plot 3, the mean

14 mid-day light environment was $4.1 \%$ of full sun (Table 1) and the ground was covered by herbaceous plants 0.4 to $0.6 \mathrm{~m}$ in height. In this plot, the 'low density' of $S$. campanulata 16 seedlings may be explained by high competition for space at ground level.

17

This research demonstrated the frequent occurrence and persistence of $S$. campanulata seedlings in shaded environments in Hawaii. Both photosynthetic rates and growth rates indicate that $S$. campanulata seedlings can maintain growth at low light levels (1-5\% of full sun). Light availabilities at the forest floor of lowland mesic forest in Hawaii were previously measured in the range of $1.5-3.8 \%$ of full sun (Pearcy 1983), implying vulnerability to invasion, but light availability in the understory of different tropical rainforests can vary significantly (Brenes-Arguedas et al. 2011, Chazdon and Fetcher 1984, Condit et al. 2000, Torquebiau 1988, Wright and Schaik 1994) and may be as low as $0.48 \%$ in some regions of 
1 the world (e.g., Chazdon and Fetcher 1984). Nevertheless, the demonstrated ability of $S$.

2 campanulata seedlings to maintain net carbon assimilation rates under very low light,

3 together with the plant's strong capacity for dispersal by wind, should be considered in

4 managing $S$. campanulata and assessing its risk of invading forests across the tropics.

\section{Acknowledgements}

We are grateful to the "Maison des Sciences de l'Homme" (MSH Clermond-Ferrand, France) and the "Secrétariat Permanent pour le Pacifique, section Fonds Pacifique" (Paris, France) for their substantial financial support for this research. We also thank two reviewers for their comments. JLB was supported by a graduate research fellowship from the National Science Foundation (Arlington, Virginia, USA).

\section{Literature Cited}

Anderson J. S., C. P. Stones, and P. K. Higashino. 1992. Distribution and Spread of Alien Plants in Kipahulu Valley, Haleakala National Park, above 2,300 ft Elevation. Pages 300-338 in C. P. Stone, Clifford W. Smith, and J. T. Tunison, eds. Alien Plant Invasions in Native Ecosystems of Hawaii. Cooperative National Park Resources Studies Unit, University of Hawaii. Honolulu.

Bärtels, A. 1993. Guide des Plantes tropicales: plantes ornementales, plantes utiles, fruits exotiques. Editions Eugen Ulmer, Paris.

Baruch, Z., R. R. Pattison, and G. Goldstein. 2000. Responses to light and water availability of four invasive Melastomataceae in the Hawaiian Islands. In. J. Plant Sci. 161:107118. 
1 Bittencourt, N. Jr., P. E. Gibbs, and J. Semir. 2003. Histological study of post-pollination

events in Spathodea campanulata Beauv. (Bignoniaceae), a species with late acting self incompatibility. Ann. Bot. 91:827-834

Bito, D. 2007. An alien in an archipelago: Spathodea campanulata and the geographic variability of its moth (Lepidoptera) communities in the New Guinea and Bismarck Islands. J. Biogeogr. 34:769-778.

Brenes-Arguedas, T., A. B. Roddy, P. D. Coley, and T. A. Kursar. 2011. Do differences in understory light contribute to species distributions along a tropical rainfall gradient? Oecologia 166:443-456.

Canham, C. D., J. S. Denslow, W. J. Platt, J. R. Runkle, T. A. Spies, and P. S. White. 1990. Light regimes beneath closed canopies and tree-fall gaps in temperate and tropical forests. Can. J Forest Res 20:620-631.

Callaway, R. M., and W. M. Ridenour. 2004. Novel weapons: invasive success and the evolution of increased competitive ability. Front. Ecol. Environ. 2:436-443.

Chazdon, R. L., and N. Fetcher. 1984. Photosynthetic light environments in a lowland tropical rain forest in Costa Rica. J. Ecol. 72:553-564.

Chazdon, R. L., 1988. Sunflecks and their importance to forest understorey plants. Adv Ecol Rs 18:1-63.

Condit, R., K. Watts, S. A. Bohlman, R. Perez, R. B. Foster, and S. P. Hubbell. 2000. Quantifying the deciduousness of tropical forest canopies under varying climates. J. Vegetation Sci. 11:649-658.

Daehler, C. C. 2003. Performance comparisons of co-occurring native and alien invasive plants: implications for conservation and restoration. Annu. Rev. Ecol. Syst. 34:183-211.

Daehler, C. C. 2005. Upper-montane plant invasions in the Hawaiian Islands: patterns and opportunities. Perspect. Plant Ecol. 7:203-216.

Denslow, J. S., J. C. Schulz, P. M. Vitousek, and B. R. Strain. 1990. Growth responses of tropical shrubs to treefall gap environments. Ecology 71:165-179.

Denslow, J. S. 2003. Weeds in paradise: thoughts on the invasibility of tropical islands. Ann. Mo. Bot. Gard. 90:119-127.

Eliovson, S. 1962. Flowering shrubs, trees, and climbers for southern Africa. South Africa: Howard Timmins, Cape Town.

Florence, J. 1997 (reprinted 2004). Flore de la Polynésie française. Collection Faune et Flore tropicale, vol 1, IRD Editions, Publications scientifiques du Muséum national d'Histoire naturelle, Paris. 
1 Fosberg, F. R., M. H. Sachet, and R. L. Oliver. 1993. Flora of Micronesia. Part 5. Bignoniaceae--Rubiaceae. Smithsonian Contrib. 81:1-135.

Francis, J. K. 2000. Spathodea campanulata Beauv., Bignoniaceae. Pages 484-487 in J. K. Francis, and C. Lowe, eds. Silvics of native and exotic trees of Puerto Rico and the Caribbean islands. USDA Forest Service, Rio Piedras, Puerto Rico.

Francis, J. K. 1990. Spathodea campanulata Beauv. African Tulip tree. Bignoniaceae.

$$
\text { Bignonia family. USDA Forest Service, Southern Forest Experiment Station, Institute of }
$$
Tropical Forestry (Rio Piedras): 1-5. Available at http://www.fs.fed.us/global/iitf/pubs/sm_iitf032\%20\%20\%285\%29.pdf

Francis, J. K., and A. Rodríguez. 1993. Seeds of Puerto Rican trees and shrubs: second installment. Research Note SO-374. U.S. Department of Agriculture, Forest Service, Southern Forest Experiment Station, New Orleans.

Gagné, WC, Cuddihy LW (1990) Vegetation. In: Wagner WL, Herbst DR, Sohmer SH (Eds) Manual of the Flowering Plants of Hawaii. University of Hawaii Press (Honolulu, USA): $45-116$.

Giambelluca, T. W., Q. Chen, A. G. Frazier, J. P. Price, Y. L. Chen, P. S. Chu, J. Eischeid, and D. Delparte. 2011. The Rainfall Atlas of Hawai‘i, USA. http://rainfall.geography.hawaii.edu.

Hierro, J. L., J. L. Maron, and R. M. Callaway. 2005. A biogeographical approach to plant invasions: the importance of studying exotics in their introduced and native range. $\mathrm{J}$. Ecol. 93:5-15.

Holdridge, L. R. 1942. Trees of Puerto Rico. US Department of Agriculture Forest Service, Washington DC.

Irvine, F. R. 1961. Woody plants of Ghana. Oxford University Press, London.

Invasive Species Specialist Group. 2004. http://www.issg.org/pdf/publications/worst_100/french_100_worst.pdf

Keay, R. W. J. 1957. Wind-dispersed Species in a Nigerian Forest. J. Ecol. 45:471-478.

Kitajima, K. 1994. Relative importance of photosynthetic traits and allocation patterns as correlates of seedling shade tolerance of 13 tropical trees. Oecologia 98:419-428.

Kobe, R. K., S. W. Pacala, J. A. Jr. Silander, and C. D. Canham. 1995. Juvenile tree survivorship as a component of shade tolerance. Ecol. Appl. 5:517-532.

Kress, W. J., and C. Horvitz. 2005. Habitat alteration in the Caribbean: natural and humaninduced. Pages 147-150 in G. Krupnick, and W. J. Kress, eds. Plant conservation: a natural history approach. University of Chicago press, Chicago and London. 
1 Kueffer, C., C. C. Daehler, C. W. Torres-Santana, C. Lavergne, J.-Y Meyer, R. Otto, and L. Silva. 2010. A global comparison of invasive plant species on oceanic islands. Perspect. Plant Ecol. 12:141-165.

Labrada, R., and A. Diaz Medina. 2009. The invasiveness of the African Tulip Tree, Spathodea campanulata Beauv. Biodiversity 10:79-82.

Larrue, S. 2011. L'extension du tulipier du Gabon (Spathodea campanulata) sur Tahiti (Polynésie Française). Pages 59-64 in A. Corvol, ed. Extension forestière et mosaïque paysagère, Environnement et Société. Cahier d'études Forêt, environnement et société XVIe-XXe siècle, $\mathrm{n}^{\circ} 21$. Institut d'Histoire Moderne et Contemporaine, ENS, Paris. Leakey, A. D. B., J. D. Scholes, and M. C. Press. 2005. Physiological and ecological significance of sunflecks for dipterocarp seedlings. J Exp Bot 56:469-482.

Little, E. L. Jr., and R. G. Skolmen. 1989. Common forest trees of Hawaii (native and introduced). Agric. Handbk. 679, USDA Forest Service, Washington DC.

Loh, R., and C. C. Daehler. 2007. Influence of invasive tree kill rates on native and invasive plant establishment in a Hawaiian wet forest. Restor. Ecol. 15:199-211.

Loope, L. L., and T. W. Giambelluca. 1998. Vulnerability of island tropical montane cloud forests to climate change, with special reference to East Maui, Hawaii. Climatic Change 39:503-517.

Loope L. L., R. J. Nagata, and A. C. Medeiros. 1992. Alien Plants in Haleakala National Park. Pages 551-577 in C. P. Stone, Clifford W. Smith, and J. T. Tunison, eds. Alien Plant Invasions in Native Ecosystems of Hawaii. Cooperative National Park Resources Studies Unit, University of Hawaii. Honolulu.

Mack, R. N., D. Simberloff, W. M. Lonsdale, H. C. Evans, M. Clout, and F. A. Bazzaz. 2000. Biotic invasions: causes, epidemiology, global consequences and control. Ecol. Appl. 10:689-710.

Martin, P. H., C. D. Canham, and P. L. Marks. 2008. Why forests appear resistant to exotic plant invasions: intentional introductions, stand dynamics, and the role of shade tolerance. Front. Ecol. Environ. 7:142-149.

Martin, P. H., R. E. Sherman, and T. J. Fahey. 2004. Forty years of tropical forest recovery from agriculture: structure and floristics of secondary and old-growth riparian forests in the Dominican Republic. Biotropica 36:297-317.

Merlin, M. D., and J. O. Juvik. 1992. Relationships among native and alien plants on Pacific islands with and without significant human disturbance and feral ungulates. Pages 597624 in C. P. Stone, W. S. Clifford, and J. T. Tunison, eds. Alien Plant Invasions in Native 
Ecosystems of Hawaii: Management and Research. University of Hawaii, Manoa, Honolulu.

Meyer, J.-Y., and J. Florence. 1996. Tahiti's native flora endangered by the invasion of Miconia calvescens DC. (Melastomataceae). J. Biogeogr. 23:775-781.

Meyer, J.-Y. 2000. A Preliminary review of the invasive plants in the Pacific Islands (SPREP Member Countries). Pp. 85-114 in Sherley, G. (compiler). Invasive Species in the Pacific. A technical review and regional strategy. South Pacific Regional Environmental Program, Apia.

Meyer, J.-Y. 2004. Threat of invasive alien plants to native flora and forest vegetation of Eastern Polynesia. Pac. Sci. 58:357-375.

Mooney, H. A., Mack RN, McNeely JA, Neville LE, Schei PJ, Waage JK (2005) Invasive Alien Species: A New Synthesis. Island Press, Washington DC.

Mueller-Dombois, D. 2002. Forest vegetation across the tropical Pacific: a biogeographically complex region with many analogous environments. Plant Ecol. 163:155-176.

Neal, M. 1948. In gardens of Hawaii. Bernice P. Bishop Museum Press, Special Pub., Honolulu.

Pearcy, R. W. 1983. The light environment and growth of C3 and C4 tree species in the understory of a Hawaiian forest. Oecologia 58:19-25.

Pearcy, R. W., R. L. Chazdon, L. J. Gross, and K. A. Mott. 1994. Photosynthetic utilization of sunflecks: a temporally patchy resource on a time scale of seconds to minutes. Pages 175-208 in M. M. Caldwell, and R. W. Pearcy, eds. Exploitation of environmental heterogeneity by plants. Academic Press, San Diego.

Pacific Islands Ecosystems at Risk. 2011. USDA Forest Service Institute of Pacific Islands Forestry, Pacific island ecosystems at risk: Spathodea campanulata. http://www.hear.org/pier/species/spathodea_campanulata.htm

Reaser, J. K., L. A. Meyerson, Q. Cronk, M. de Poorter, L. G. Eldrege, E. Green, M. Kairo, P. Latasi, R. N. Mack, J. Mauremootoo, D. O’Dowd, W. Orapa, S. Sastroutomo, A. Saunders, C. Shine, S. Thrainsson, and L. Vaiutu. 2007. Ecological and socioeconomic impacts of invasive alien species in island ecosystems. Environ. Conserv. 34:98-111.

Rejmánek, M. 1996. Species richness and resistance to invasions. Pages 153-172 in G. Orians, R. Dirzo, and J. H. Cushman, eds. Biodiversity and ecosystem processes in tropical forests. DE: Springer-Verlag, Berlin. 
1 Rijkers T., P. J. Vries de, T. L. Pons, and F. Bongers. 2000. Photosynthetic induction in saplings of three shade-tolerant tree species: comparing understorey and gap habitats in a French Guiana rain forest. Oecologia 125:331-340

Schumacher, E., C. Küffer, M. Tobler, V. Gmür, P. J. Edwards, and H. Dietz. 2008. Influence of Drought and Shade on Seedling Growth of Native and Invasive Trees in the Seychelles. Biotropica 40:543-549.

Smith, C. W. 1985. Impact of alien plants on Hawaii's native biota. Pages 180-250 in C. P. Stone, and J. M. Scott, eds. Hawaii's terrestrial ecosystems: preservation and management. University of Hawaii, Cooperative National Park Resource Studies Unit, Honolulu.

Staples, G. W., and D. R. Herbst. 2005. A tropical garden flora: Plants cultivated in the Hawaiian Islands and other tropical places. Bishop Museum Press, Honolulu.

Staples, G. W., and R. H. Cowie. 2001. Hawaii's Invasive Species: a guide to the invasive alien animals and plants of the Hawaiian Islands. Mutual Publishing and Bishop Museum Press, Honolulu.

Staples, G. W., D. R. Herbst, and C. T. Imada. 2000. Survey of invasive or potentially invasive cultivated plants in Hawai'i. Bishop Museum Occasional Papers 65:1-35.

State of Hawaii Data Book. 2004. State of Hawaii. http://www.hawaii.gov/dbedt/

Thompson, J., A. E. Lugo, and J. Thomlinson. 2007. Land use history, hurricane disturbance, and the fate of introduced species in a subtropical wet forest in Puerto Rico. Plant Ecol. 192:289-301.

Torquebiau, E. F. 1988. Photosynthetically active radiation environment, patch dynamics and architecture in a tropical rainforest in Sumatra. Aust. J. Plant Physiol. 15:327-342.

Unwin, A. H. 1920. West Africa forest and forestry. E.P. Dutton and Compagny, New York. Wagner, W. L., D. R. Herbst, and S. H. Sohmer. 1999. Manual of the flowering plants of Hawai'i. Rev. ed. University of Hawai ‘i Press and Bishop Museum Press, Honolulu. Weber, E. 2003. Invasive plant species of the world: a reference guide to environmental weeds. CT: CABI Publishing, Wallingford.

Wright, S. J., and C. P. Schaik. 1994. Light and the phenology of tropical trees. Am. Nat. 143:192-199. 


\section{FIGURES AND CAPTIONS}

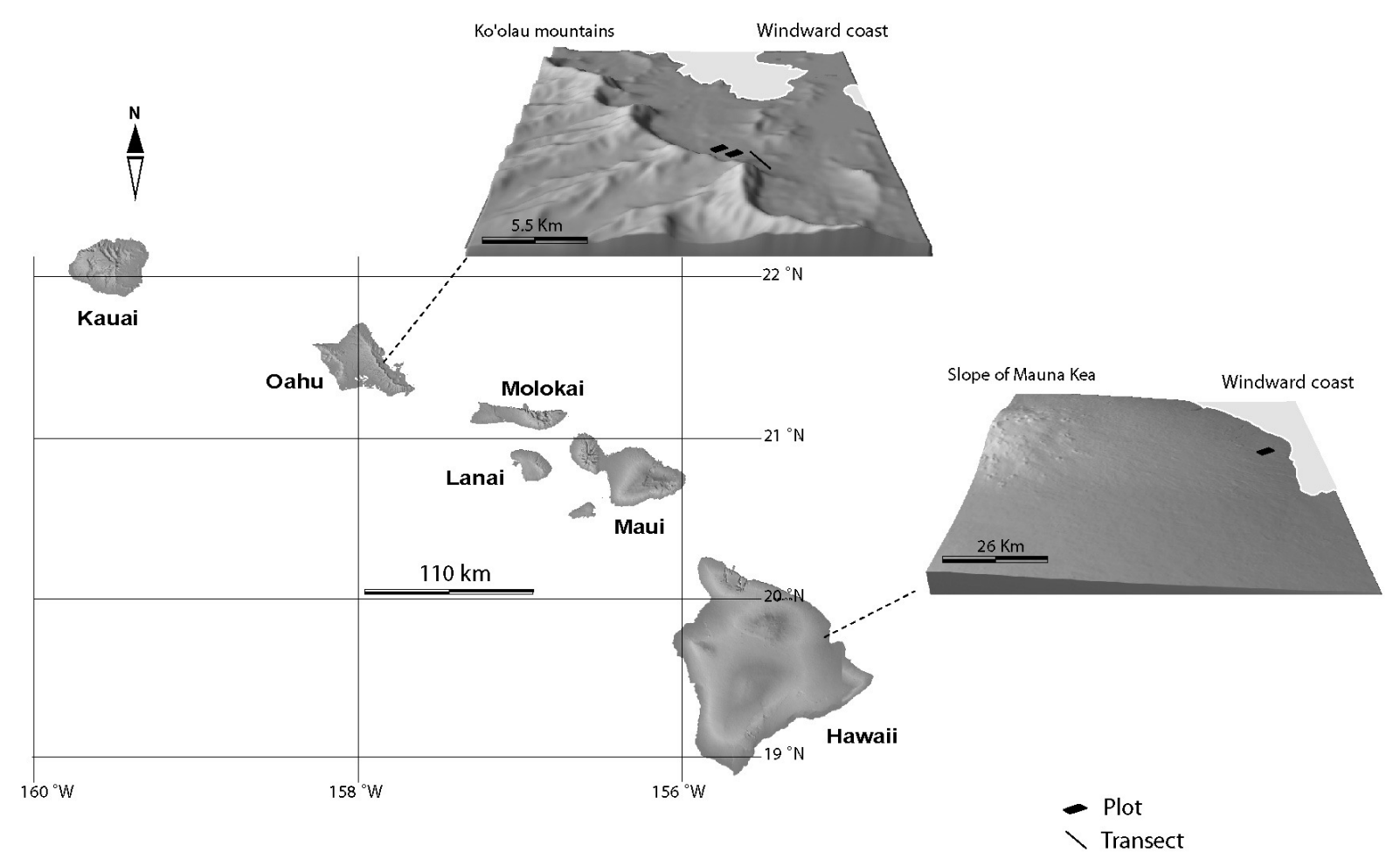

Figure 1. Location of study sites on the islands of Oahu and Hawaii (Hawaiian Islands). 


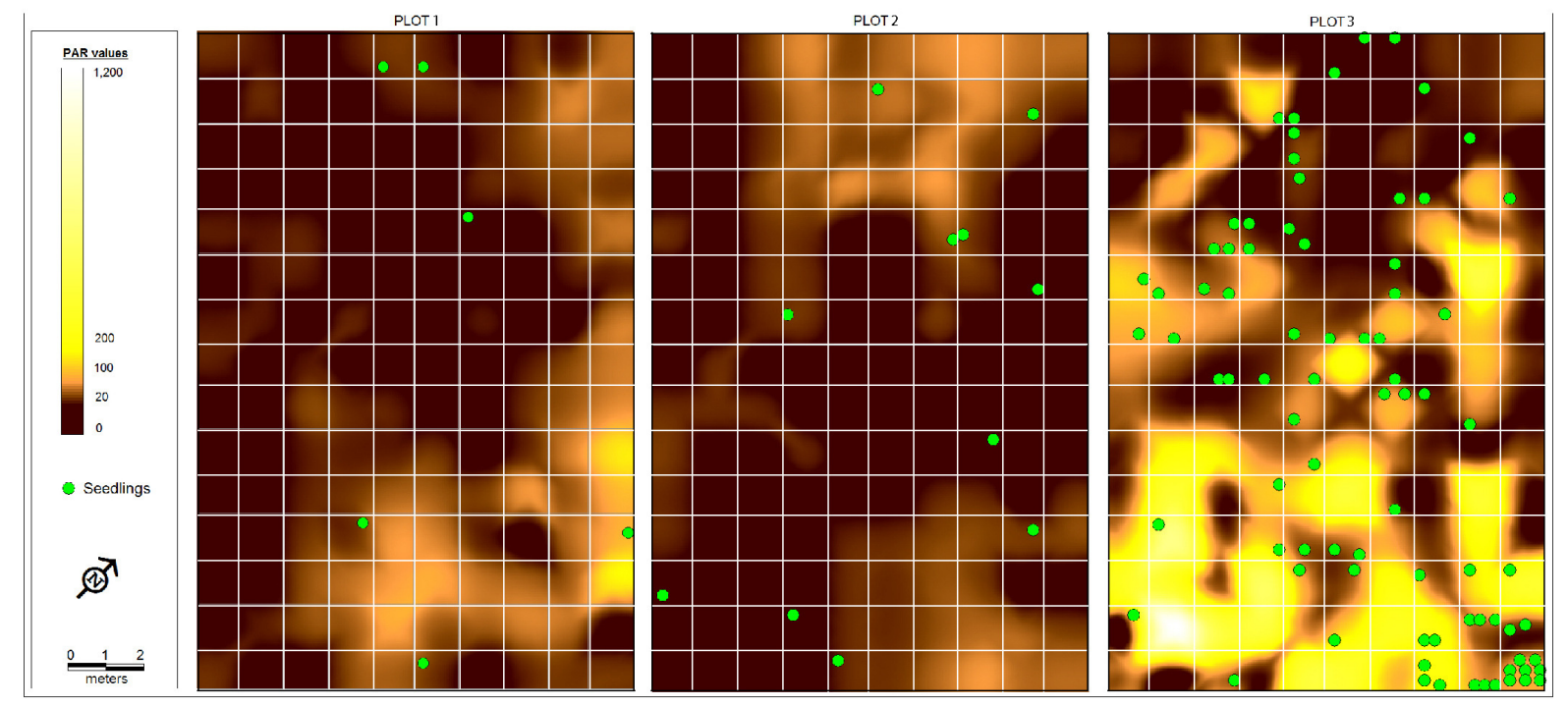

Figure 2. Spatial pattern of seedlings (mean height $10 \mathrm{~cm}$ ) and photosynthetically active radiation (PAR) in closed forests (plots 1 and 2) and tree grove (plot 3) near solar noon as estimated by interpolation (GIS Mapinfo Professional v.10). 


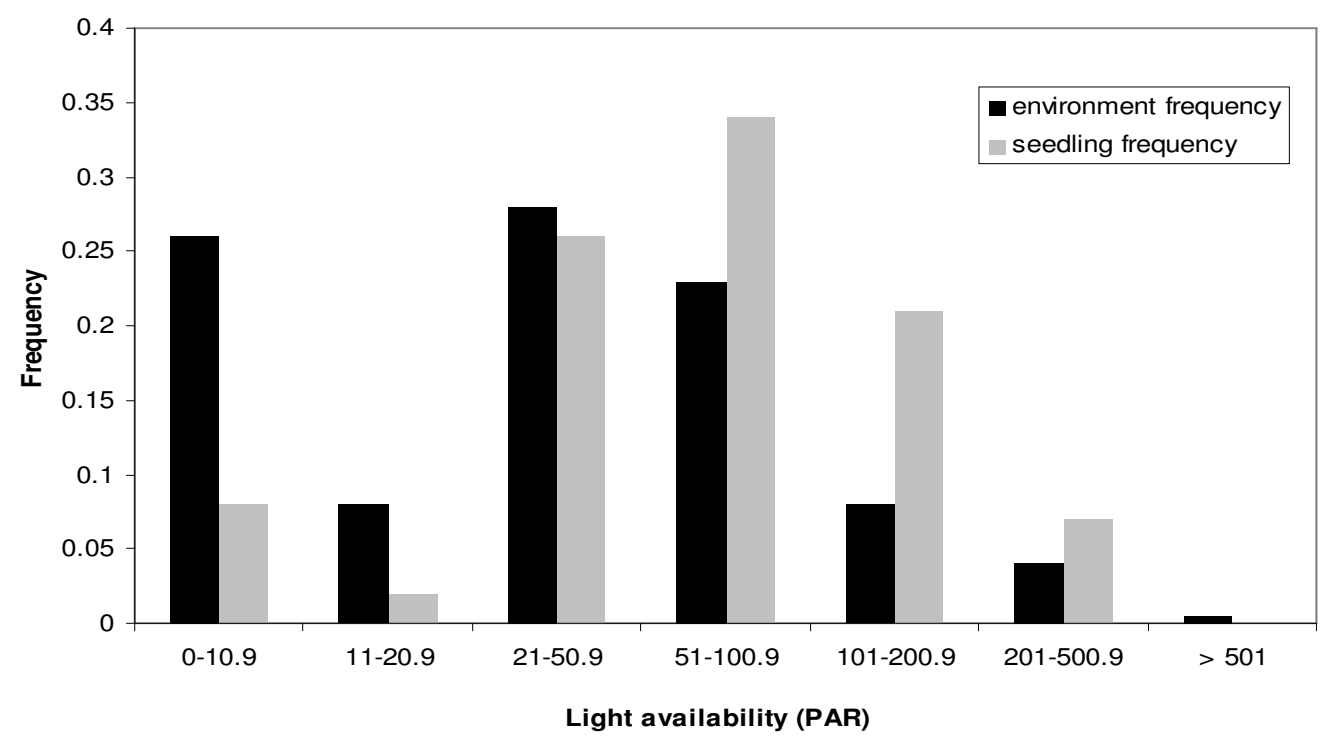

Figure 3. Distribution of light environments in the plots as compared to distribution of Spathodea campanulata seedlings (mean height $10 \mathrm{~cm})$ among those light environments $(\mathrm{n}=$ 97 seedlings). 


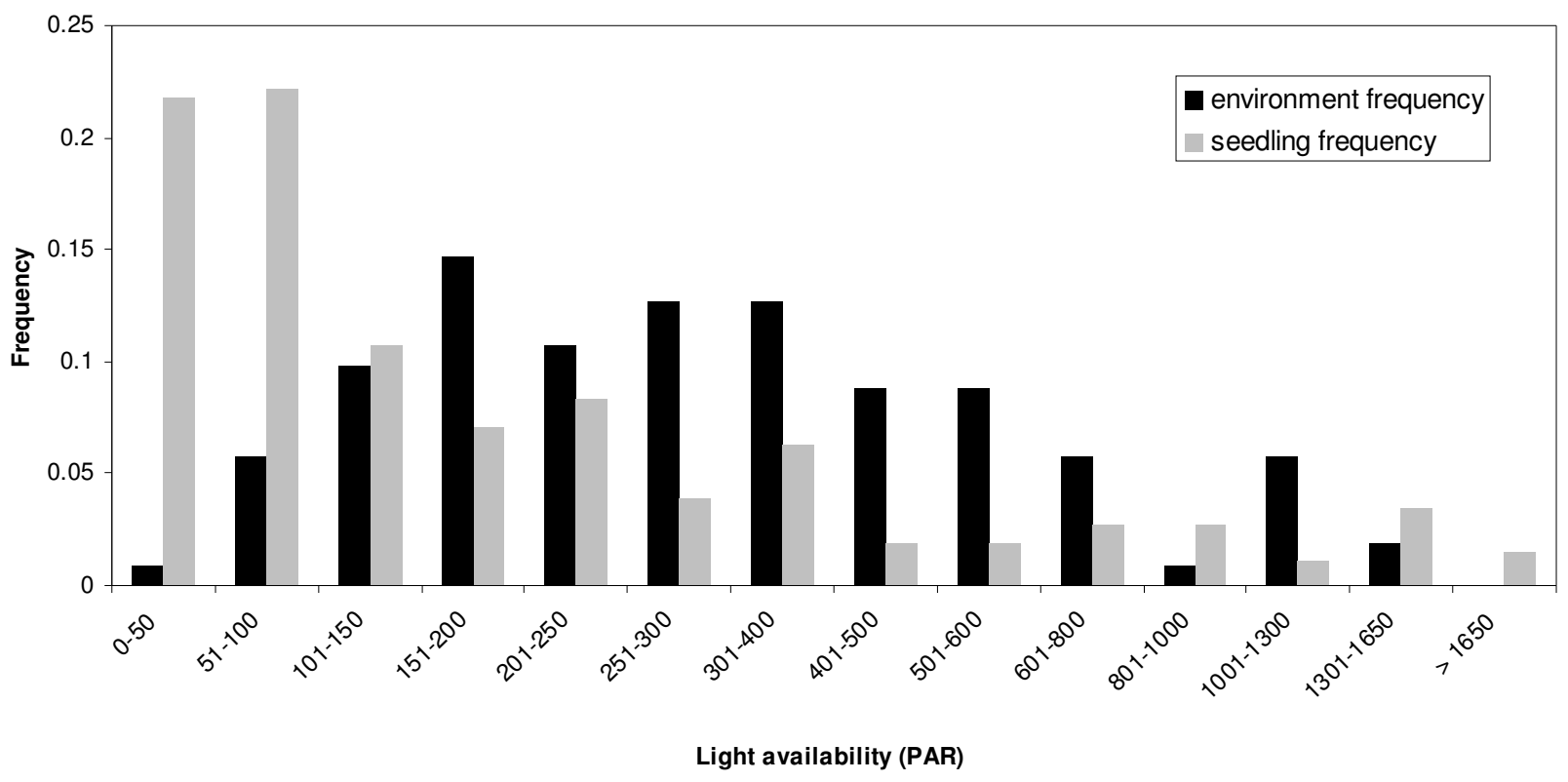

Figure 4. Distribution of light environments (random points) along a 1.5-km line transect as compared to distribution of Spathodea campanulata seedling (mean height $12.5 \mathrm{~cm}$ ) frequency $(\mathrm{n}=255$ seedlings $)$. 


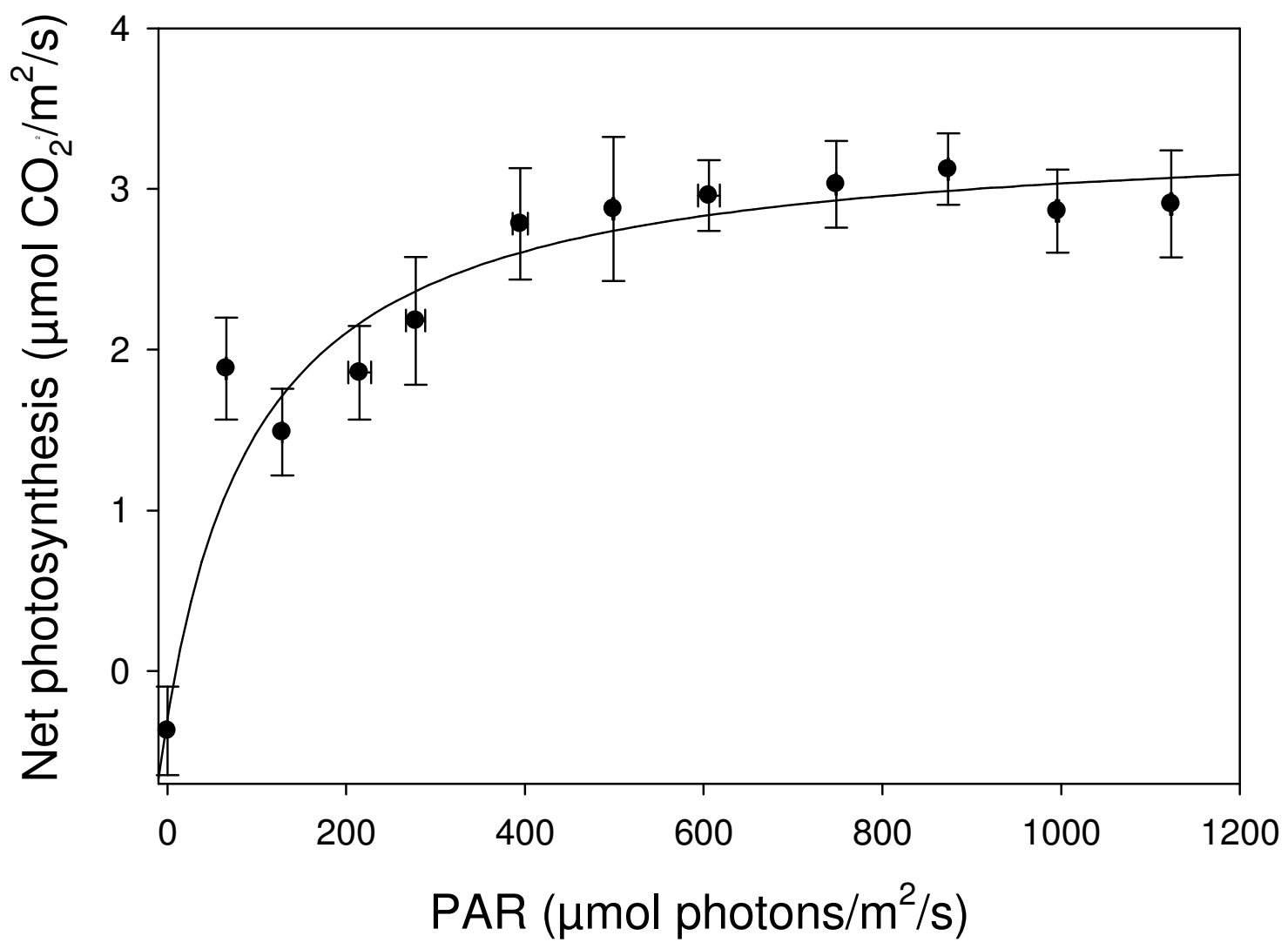

Figure 5. Light response curve for Spathodea campanulata seedlings (mean height $7.5 \mathrm{~cm}$ ). Error bars indicate $\pm 1 \mathrm{SE}(\mathrm{n}=10$ seedlings $)$. 


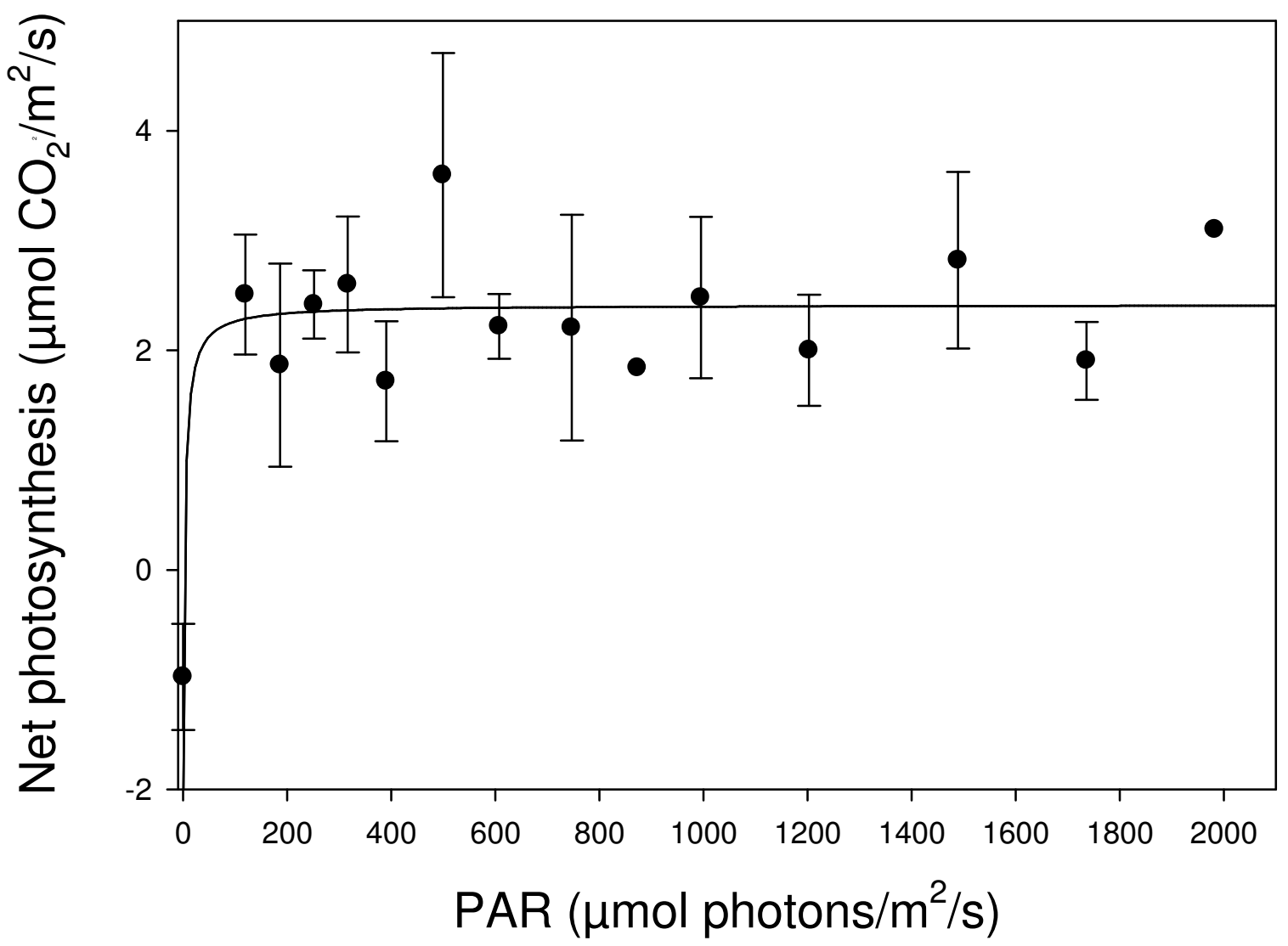

Figure 6. Light response curve for Spathodea campanulata seedlings ( $\mathrm{n}=7$ seedlings; mean height $11 \mathrm{~cm}$ ) naturally established in shade (mid-day PAR ranging from 1-150 $\mu$ mol photons $\left.\mathrm{m}^{-2} \cdot \mathrm{s}^{-1}\right)$ 


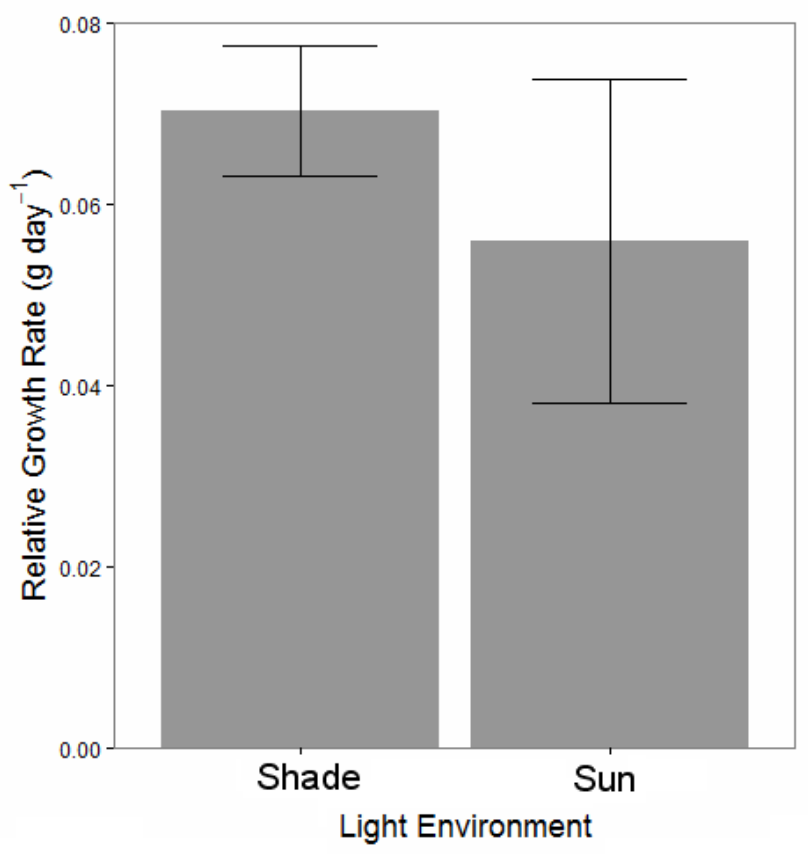

Figure 7. Average relative growth rate from seed to seedling with four true leaves in shaded (10\% light) and full light environments. Seedlings were grown in containers with ample water. There was no statistical difference in growth rates between environments. Error bars indicate SE. 


\section{TABLE}

Table 1. Characteristics of the plots $\left(150 \mathrm{~m}^{2}\right)$ with GPS coordinates, elevation, dominant trees, number and density of seedlings, and light environment.

\begin{tabular}{|c|c|c|c|}
\hline Plots & 1. Closed forest (Plot 1) & 2. Closed forest (Plot 2) & 3. Trees grove (Plot 3) \\
\hline Central Elevation & $126 \mathrm{~m}$ & $123 \mathrm{~m}$ & $117 \mathrm{~m}$ \\
\hline Central GPS point & $21^{\circ} 22.22^{\prime} 05^{\prime \prime N} / 157^{\circ} 47^{\prime} 30.40^{\prime \prime W}$ & $21^{\circ} 22.22^{\prime} 30^{\prime \prime N} / 157^{\circ} 47^{\prime} 29.75^{\prime \prime W}$ & $19^{\circ} 52^{\prime} 0.576^{\prime \prime} \mathrm{N} / 155^{\circ} 06^{\prime} 41.95^{\prime \prime W}$ \\
\hline \multicolumn{4}{|l|}{ Dominant trees $(>15 \mathrm{~m})$} \\
\hline Spathodea campanulata (Bignoniaceae) & 14 & 18 & 7 \\
\hline Leucaena leucocephala (Mimosaceae) & & & 2 \\
\hline \multicolumn{4}{|l|}{ Trees species under canopy (1-5 m) } \\
\hline S. campanulata & 3 & 3 & 4 \\
\hline Hibiscus tiliaceus (Malvaceae) & 1 & & \\
\hline Syzygium cumini (Myrtaceae) & 1 & 1 & \\
\hline Persea americana (Lauraceae) & 2 & 1 & \\
\hline Cinnamomum burmannii (Lauraceae) & 1 & 1 & \\
\hline Psidium guajava (Myrtaceae) & & & 1 \\
\hline \multicolumn{4}{|l|}{ Light environment in the plots } \\
\hline Perception of visual light environment & Deep shade & Deep shade & Shade \\
\hline Range of PAR ( $\mu \mathrm{mol}$ photons $/ \mathrm{m} 2 / \mathrm{s}$ ) & $0-77.9$ & $0-139.6$ & $0-1,107$ \\
\hline Median PAR (PAR full sun: $1,884 \pm 3.5(100 \%))$ & $19.4(1 \%)$ & $27.3(1.4 \%)$ & $77.3(4.1 \%)$ \\
\hline \multicolumn{4}{|l|}{ Seedlings in the plots } \\
\hline Total of $S$. campanulata seedlings (mean height $10 \mathrm{~cm}$ ) & 6 & 11 & 80 \\
\hline Density (Seedlings $/ \mathrm{m}^{2}$ ) & 0.04 & 0.07 & 0.54 \\
\hline Range of PAR ( $\mu \mathrm{mol}$ photons $/ \mathrm{m} 2 / \mathrm{s}$ ) & $11.7-109$ & $1-61.1$ & $1.4-412.8$ \\
\hline Median PAR of the seedlings & 45.9 & 37.2 & 76.5 \\
\hline
\end{tabular}

